\title{
Consumer Ethnocentrism and Its Influence on Impulsive Buying Behav- iour in Sri Lankan Milk Powder Market: The Moderation Effect by the Consumer Impulsiveness Traits
}

\author{
Karunaratne L.G.A.S ${ }^{1}$ and Wanninayake W.M.C.B ${ }^{2}$ \\ University of Kelaniya \\ anitashiranthi@gmail.com¹ and bwanninayake@gmail.com²
}

\begin{abstract}
The dairy industry faced an unexpected and serious crisis regarding the Dicyandiamide (DCD) factor. Then an impulsive buying situation was raised and the milk powder brands were focusing on the ethnocentric appeal to rebuild their brands in the market. In buying the milk powder brand in this impulsive situation the impulsiveness personality trait of the customer has raised as an influential for the buying process. Therefore, identifying the impact of the Ethnocentrism on the Consumer Impulsive Buying Behaviour moderated by the Consumer Impulsiveness trait is the key issue of this study. The hypotheses were formulated to verify the relationship between the variables; in order to answer the research questions. The data collection was done with a sample of 350 consumers. The tool used to collect data was a questionnaire and it was developed using already developed measurements by researchers. The key findings of the study were that the Sri Lankan dairy product consumers have medium level Impulsiveness and there is a positive relationship between Ethnocentrism and Impulsive Buying Behaviour. But when this relationship is moderated by the Impulsiveness trait the relationship gets stronger. When the ethnocentric consumers involve in the purchasing, most of the time, goes with a pre-planned purchasing decision. Therefore, all the local and multinational companies should get into activities that can stimulate and arouse the impulsiveness personality trait of the milk powder consumers. Then the consumers who have the ethnocentrism trait will stimulate to go for impulsive buying.
\end{abstract}

Keywords: Consumer Ethnocentrism, Consumer Impulsiveness, Consumer Impulsive Buying Behaviour, Milk Powder Market, Sri Lanka

Copyright: (C) 2018 Karunaratne L.G.A.S., Wanninayake W.M.C.B. This is an open access article distributed under the Creative Commons Attribution License, which permits unrestricted use, distribution, and reproduction in any medium, provided the original work is properly cited.

Correspondence: anitashiranthi@gmail.com

ORCID of authors: Karunaratne L.G.A.S. - https://orcid.org/0000-0001-6471-553X

Wanninayake W.M.C.B. - https://orcid.org/0000-0002-5202-4077

DOI: http://10.4038/kjm.v7i2.7574 


\section{Introduction}

Milk powder market is a very complex and competitive market in Sri Lanka where domestic brands and international brands are operating in a competitive manner. Domestic Dairy industry has capability of producing substantial amount of quality milk and milk products to the prevailing market at affordable prices while keeping reasonable profit margins to all stakeholders in the production marketing chain and government policy is encouraging the local milk production and fresh milk consumption (Mangaleswaran., Morais, \& Jeyaseelan, 2010). But currently the international dairy brands especially the milk powder brands are playing a bigger role in the Sri Lankan market. The marketing of milk in Sri Lanka is complex and varied (Ranaweera, 2010). The dairy product marketing practices are more focused on the customers and their buying behavior patterns due to the growing demand (Bogahawatte \& Herath , 2006).

The buying patterns are more impacted by the customer psychological factors such as perception, cognition, attention, emotion, phenomenology, motivation, brain functioning, interpersonal relationship and personality. In the buying behavior patterns the impulsive buying behavior is special occasion. For the impulsive buying behavior also, the same factors which impact the buying behavior is influencing. In this impulsive buying behavior pattern personality is very important factor (Wanninayake \& Chovancova, 2012). According to the consumer personality, the customer is willing to do their purchasing. There is a high competition in the milk powder market and recently the industry faced a real crisis regarding the milk powder quality. Basically, the milk powder products can be identified as local and foreign brands. Some local and foreign brands are focusing on the local brand biasness and come up with the brand activations and other marketing activities. With the special DCD factor crisis in the market, the foreign brands had to face a huge problem in Sri Lankan market. Especially with the milk powder crisis, the customers motivated got impulse buying of the milk powder brands. Then the milk powder brands (mostly the multinational companies) started to market their products using the ethnocentric appeal. For the customers to buy the products in impulsive manner, the level of impulsiveness of the customer personality is influenced. Therefore, this research study focuses the impact of the Ethnocentrism trait on impulsive buying behavior that is moderated by the consumer impulsiveness personality trait.

In the crisis situation most customers rejected some international dairy brands due to DCD context. However strategically some marketers promote their brands to the consumers based on ethnocentric appeal. However there is no sufficient empirical evidence to say their effort is successful. As a result there is a significant literature gap relating to Sri Lankan context. Therefore the present study is designed to fulfill that literature and empirical gap as much as possible.

The objectives of this study are; to identify the level of impulsiveness of milk powder consumers in Sri Lanka and to understand how far the impulsiveness trait impact on the relationship between the ethnocentrism and impulsive buying behavior of Sri Lankan milk powder consumers. The research questions of this study are what is the level of impulsiveness of milk powder consumers in Sri Lanka and to understand how far the impulsiveness trait impact on the relationship between the ethnocentrism and impulsive buying behavior. In the literature review chapter, it is provided the previous knowledge available related to the variables of the research study. The methodology chapter provides the information on how the research is designed and conducted, the conceptual framework, the hypotheses, operationalization and the analytical methods used in 
this study. In the findings and discussion chapter, it presents the data analysis, the findings and the interpretation of the empirical data. In the final chapter of conclusion and the recommendation it is presented the final conclusion of the study and the recommended suggestions for the stakeholders of the milk powder market especially the marketers of the milk powder companies.

\section{Literature Review}

\subsection{Consumer Ethnocentrism}

Consumer Ethnocentrism can be defined as "the beliefs held by consumers about the appropriateness, indeed morality of purchasing foreign-made product and the loyalty of the consumers to the products manufactured in their home country" (Shimp \& Sharma, 1987). Herche (1992) found that consumer ethnocentric appeal can predict consumers' preferences to buy domestically produced goods instead of foreign and that the ethnocentric tendencies are better predictors of purchase behavior than demographic or marketing mix variables. The construct of consumers' local brand biasness relies on the presumption that the consumers' patriotic emotions will have significant effects on attitudes and purchase intentions. Therefore, Shoham \& Brenecic (2003) reported that ethnocentric appeal had a significant impact on consumers' intentions to purchase domestically produced goods.

Literature suggest that consumers' ethnocentrism appeal depend on the degree of the development of the country. The original concept of consumer ethnocentrism has emerged in developed countries where consumers generally positively evaluated the quality of domestic products (Herche, 1992; Elliot \& Cameron, 1994; Ahmed et al., 2004). Recent researches (Supphellen \& Gronhaug, 2003; Reardon, et al., 2005; Klein, et al., 2006) have shown that the same concept is applicable in the context of developing countries. Kaynak \& Kara
(2002) have noted that significant population growth and increasing purchasing power of consumers in such developing countries offer market opportunities to foreign companies whose domestic markets have already reach maturity.

CETScale that was developed by Shimp \& Sharma 1987, is a successful predictor of consumers' beliefs, attitudes, purchase intentions and decision. This scale has been widely used to measure consumer ethnocentrism trait in many studies within developed and in the developing countries. Although other scales have subsequently been suggested and tested, CETScale has become the most commonly used instrument for measuring consumer Ethnocentrism (Renko, Karanovic, \& Matic, 2012).

\subsection{Consumer Impulsiveness}

From a behavioral perspective, impulsiveness can be defined as 'a wide range of actions that are poorly conceived, prematurely expressed, unduly risky, or inappropriate to the situations and that often result in undesirable outcomes' (Evenden, 1999). More simply, it is described as the inability to delay gratification or the inverse of self-control (Monterosso \& Ainslie, 1999).

Impulse purchases are a common occurrence and billions of money is spent for the in store advertising like merchandizing, in attempt to increase impulse buying of the consumers in the store. A 1995 report from the Point of Purchase Advertising Institute finds that over two-third of purchase decisions are made at the store. The consumer is taking the decisions to buy the products without thinking; this may cause a risk taking. Strong emotions can be seen as factors that always act between cognition and action leading to behavior that can be assessed as more or less impulsive or self-controlled. According to Youn \& Faber (2000), impulsiveness is a major factor that influences the impulsive buying. Previous studies done for the im- 
pulsiveness of the consumers say that impulsivity is becoming increasingly apparent in studies of decision making; from the most simple action inhibition task to elaborated paradigm where the evaluation of future consequences depends on the immediate choice (Arce \& Santisteban, 2006). In study done at Sri Lankan market reveals that the impulsiveness is very much higher in the Sri Lankan consumers (Wanninayake \& Chovancova, 2012).

Impulsiveness is a complex concept to define as well as to measure. Some of the most common instruments to measure impulsiveness in human are the matching familiar figures test, the Porteus maze, and the Barratt impulsiveness scale. To measure the impulsiveness commonly used scale is Barratt Impulsiveness Scale. The Barratt impulsive scale is a questionnaire designed to assess the personality/ behavioral construct of impulsiveness. It is most widely cited instrument and has been used to advance the understanding of the construct and the relationship for the other phenomena. The current version of the Barratt Impulsiveness scale is composed of 30 items describing common impulsiveness or non-impulsiveness. The perspective of Dr. Barratt and International Society for Research on Impulsivity is that impulsivity is a multi-faceted construct and this multi-dimensionality is reflected in the BIS-11 factor structure.

\subsection{Impulsive Buying Behaviour}

The impulsive buying behavior is an unplanned decision to buy a product or a service, made just before a purchase. Rook \& Gardner (1993), defined impulse buying as an unplanned behavior involving quick decision making and tendency for immediate purchasing of the product. According to Beatty \& Ferrell (1998), the impulse buying refers to immediate purchase which is without any pre-shopping objective either to purchase the specific product category or to fulfill a specific need. Rook (1987) argued that during impulse buying, the consumer experiences an instantaneous, overpowering and persistent desire. He characterized the impulse buying as unintended, non-reflective reaction, which occurs soon after being exposed to stimuli inside the store. According to Engel \& Blackwell (1982), impulse buying is an action undertaken without previously having been consciously recognized or a buying intention formed prior to entering the store (Engel \& Blackwell, 1982). Based upon the different description, researchers conclude that impulse buying involves hedonic purchase decisions which are made inside a store and excludes the reminder purchasing activities (Muruganantham \& Kaliyamoorthy, 2005).

The classification of a purchase planned or impulse began with the Stern (1962) study where he provided the basic framework of impulse buying by categorizing a buying behavior as planned, unplanned or impulse. Planned purchases involve time consuming, information searching with rational decision making; whereas unplanned buying refers to all shopping decisions made without any advance planning. Impulse buying is distinguished from the unplanned buying in terms of quick decision making. In addition to being unplanned, an impulse purchase also involves experiencing a sudden, strong and irresistible urge to buy. Pure impulse buying is novelty or escape purchase which a shopper breaks the trend of usual shopping (Stern, 1962). Han et.al, (1991) described fashion oriented impulse as a type of suggestion impulse where the purchase is motivated by self-suggestion to buy the new fashion product. In case of fashion oriented impulse buying, shopper has no previous experience with the new and fashionable product. Mattila \& Enz (2002) later argued that fashion oriented impulse buying can be influenced by shopper's own positive emotions when shopping. According to Rook \& Hoch (1985), buying impulses actually begin with a consumer's sensation and perception driven by the external stimulus, and 
are followed by a sudden urge to buy. Mattila \& Wirtz (2008) found that store environmental stimuli positively affect impulse buying behavior especially when the store environment is perceived as over-stimulating. Stimuli in the retail store environment are likely to affect consumer emotions (Donovan, Rossiter, \& Marcoolyn, 1994), which are other variables that have been found to affect the impulse purchases (Rook, 1987; Zhou \& Wong, 2003).

Dawson \& Kim (2009) observed that impulse buying is linked to up and cross-selling strategies. Yu \& Bastin (2010) studied the effect of in-store Point of Purchase (POP) posters in supermarkets and found them to induce impulse purchase behaviors and cost-effective. In-store stimuli are promotional techniques employed to increase impulse buying of products. Some examples of these techniques include instore settings, on-shelf positions, price-off promotions, sampling, and point of payment (POP) displays, coupons, and instore demonstration. Today with the technology innovations not only the shopping environment but also the online buying environment also can be seen. Currently the online impulse buying also is a new area for the researchers.

\subsection{Association between Impulsive- ness, Ethnocentrism and Impulsive Buying Behaviour}

According to the objectives of this study, identifying the association between Ethnocentrism and Impulsive Buying Behavior is very important. With the DCD factor issue lot of consumers suddenly changed and switched to different diary brands. Therefore lot of multinational brands who were the main players in the market lost their market share. Currently they are trying to rebuild the brands using many brand activations and promotions using the Ethnocentrism application. Therefore there should be a considerable association between Impulsiveness, Ethnocentrism and
Impulsive Buying Behavior in the dairy product market.

Baumeister (2002) argued that high arousal and overstimulation lessens people's self-regulation and also tends to reduce people's ability think through their actions which could further increase the chances of impulse buying. Gupta et.al, (2009) suggested that when size of the store is concerned product display and product prices were the major in-store stimuli in large stores. For small-sized stores, product price was the main factor that attracted impulse purchases. Retail merchandising instantly motivates a consumer to buy a product. Merchandising activities act as a silent salesman in the retail outlet (Muruganantham \& Kaliyamoorthy, 2005). Zhou \& Wong (2003) described that informative and experiential aspect of POP poster may influence impulse buying. Consumer's propensity to purchase on impulse receives a further impetus when they see an item on sale (Ramaswamy \& Namakumar, 2009). Hulten \& Vanyushyn (2011) also observed that impulsive buyers are giving more attention to the in-store displays and offerings. Yu \& Bastin (2010) studied the effect of in-store Point of Purchase (POP) posters in supermarkets and found them to induce impulse purchase behaviors and cost-effective. In-store stimuli are promotional techniques employed to increase impulse buying of products. Some examples of these techniques include in-store settings, on-shelf positions, price-off promotions, sampling, POP displays, coupons, and in-store demonstration that arouse the impulsive trait of the consumers.

Internal Stimuli are related to the different personality related factors such as ethnocentrism, impulsiveness which characterizes an individual rather than the shopping, online environment or stimuli. Internal factors of impulse buying denote the individual's internal cues and characteristics that make the customer to engage in 
impulse buying. Weinberg \& Gottwald (1982) initially established that impulse buyers exhibited greater feelings of amusement, delight, enthusiasm, and joy. Chang et.al, (2011) argued that consumers who had more positive emotional responses to the retail environment were more likely to make impulsive purchases. Impulse purchases are more likely to happen when shoppers evaluate the purchase as appropriate (O'Guinn \& Faber, 1989) .

Previous researchers have empirically studied the impact of Ethnocentrism on Impulsive Buying Behavior of customers. Most of researchers (Youn \& Faber (2000); Wanninayake \& Chovancova, 2012) noted that the intensity of Impulsive Buying intention can be vary in different context. On the other hand few researchers only investigated on association between consumer ethnocentrism and impulsive buying behavior. However there is no consensus in previous researches regarding those phenomena. When it comes to Sri Lankan context Impulsive Buying Behavior can be seen commonly in dairy products due to rapidly changing macro factors.

According to a study done in Sri Lankan market regarding the ethnocentrism and impulsiveness of the Sri Lankan consumers says that the ethnocentrism trait, the impulsiveness and the stimulation to make buying decisions are above the average in Sri Lankan context. Furthermore, high ethnocentric and impulsive customers displayed a high tendency of making impulsive decisions to buy local brands rather than high ethnocentric and low impulsive customers (Wanninayake \& Chovancova, 2012). Therefore, the present study is designed to fulfill the literature gap of how far the consumers have the Ethnocentric trait and how it impacts on the impulsive buying behaviour of the consumers in Sri Lankan milk powder market moderated by the impulsiveness personality trait.

\section{Conceptualization and Hy- potheses Development}

\subsection{Conceptual Framework and Hy- potheses}

The conceptual model for this study is designed as follows. The Consumer Ethnocentrism is the independent variable and the Consumer Impulsive Buying Behavior is the dependent variable. The relationship of the Consumer Ethnocentrism and the Consumer Impulsive Buying Behaviour is moderated by the Impulsiveness trait of the consumers. See Figure 1. Conceptual framework.

Previous studies about ethnocentric appeal have revealed many factors about the consumer behaviors. One study says that the concept of consumer ethnocentrism can improve understanding of how consumers and corporate buyers compare domestic with foreign made products and how and why their judgments may be subject to various forms of bias and error (Nisbett \& Ross 1980; Jhon, Scott \& Bettman 1986). Another study says that highly ethnocentric consumers are probably most prone to biased judgments by being more inclined to accentuate the positive aspects of domestic products and to discount the virtues of the foreign made products (Shimp \& Sharma, 1987). Especially the research done in Sri Lankan market, reveals that young educated customers in Sri Lanka are willing to buy local brands of consumer products (Wanninayake \& Chovancova, 2012). According to a study done in Sri Lankan market regarding the ethnocentrism and impulsiveness of the Sri Lankan consumers says that the ethnocentric appeal, the impulsiveness and the stimulation to make buying decisions are above the average in Sri Lankan context. Furthermore, high ethnocentric and impulsive customers displayed a high tendency of making impulsive decisions to buy local brands rather than high ethnocentric and low impulsive customers (Wanninayake \& Chovancova, 2012). 
Based on the previous researches the researcher has developed following hypotheses.

H1: Impulsiveness personality trait has a positive and medium effect on the relationship of the ethnocentrism and impulsive buying behavior

H2: Sri Lanka milk powder customers have medium level of impulsiveness level.

H3: Sri Lankan milk powder customers have medium involvement in ethnocentric appeal.

\subsection{Methodology}

The research study is quantitative study and a field survey was conducted among the selected sample of milk powder users. They were asked about their personality trait tendency using popular models for the variables of Ethnocentrism, Impulsiveness and Impulsive Buying Behaviour. Data collection was done through the survey strategy using a self- administrative questionnaire as the instrument. For the research survey the population was all the milk powder users in Sri Lankan market. From the population, 350 people were selected as the sample using non probability convenient sampling method. No uncompleted or rejected questionnaires were found. Accordingly, the sample consisted with 123 male and 227 female.

The questionnaire was consisted with questions regarding ethnocentrism, impulsiveness and impulsive buying behaviour, mainly and relevant few demographic factors also included. Consumer Domestic brand biasness Tendency Scale (CETScale) was used to measure the ethnocentric appeal of the sample. For the consumer impulsiveness the Barrette's Impulsive Scale (BIS) was used consist of 14 questions. To operationalize the impulsive buying behaviour the scale developed by Irem Gure in 2012 was used. All the scales were scored on a five point likert scale ranging 1 (strongly disagree) to 5
(Strongly agree). Data analyzing was done using the SPSS 19 package and 100 percent accuracy checked when feeding the data to the SPSS format. As the descriptive statistics the mean and standard deviation were presented. The model summary was derived by running a multiple regression analysis. The moderator test was done for the impulsiveness moderator variable. Next chapter presents the findings of the analysis.

\section{Findings and Discussion}

A reliability analysis was done to measure the internal consistencies of the total scores for each scale through Cronbach's Alpha Coefficient. The analyzed data was reliable according to the Cronbach's Alpha coefficient as the all values were above 0.7 . Therefore the data on three variables are accepted as reliable and consistent. See Table 1. Reliability Statistics.

The descriptive statistics of each and every scale statement got mean and standard deviation as follows. See Table 2. Descriptive Statistics- Impulsiveness trait.

According to descriptive statistics shown in the table 2 the impulsive trait gets 3.43 average mean value (in the range of 2.33 and 3.67) and 0.41636 standard deviation. In Sri Lankan context impulsiveness is in a middle level. 53 percent of the Sri Lankan milk powder product users are preplanning the purchasing decisions. Impulsivity of the consumers in milk powder market is in a moderate level.

According to the empirical data the mean values for the Ethnocentrism trait items were as follows. See Table 3. Descriptive Statistics- Consumer Ethnocentrism.

According to descriptive statistics shown in table the Consumer Tendency Scale gets the average mean value of 3.28 (in the range of 2.33-3.67) which reveals that in Sri Lankan context the Ethnocentrism is in medium level. According to the frequency of the scale, Sri Lankans are not very 
much concerning about the ethnocentric ideas when they decide on the purchasing at dairy product market. See Table 4 . Descriptive Statistics - Impulsive Buying Behaviour.

According to the descriptive statistics of impulsive buying behavior scale shown in the table the average mean value is 3.16 (in the range of 2.33 and 3.67). In Sri Lankan context the milk powder consumer impulsive buying behavior is in middle level. See Table 5. Correlation Summary.

As per the correlation statistics, Ethnocentrism trait and Impulsive Buying Behaviour has a positive relationship of 0.214 which is not very much stronger relationship. But in a 95 percent confidence level these two variables have positive relationship. The moderating variable Impulsiveness trait has a positive relationship of 0.241 with Impulsive Buying Behaviour variable that is not a very strong relationship. This relationship also significant under 0.000 significance level and 95 percent confidence level. See Table 6. Model Summary.

The $t$ value of the relationship between the Ethnocentrism trait and Impulsive Buying Behaviour before moderated by the Impulsiveness trait is 3.471 and after moderated by the Impulsiveness trait the $t$ value is 4.034 that there is a positive moderating effect for the relationship between the independent and dependent variables. The impact of Ethnocentrism trait is 4.2 percent before the moderating effect. But after moderated by the Impulsiveness trait the impact of the Independent variable on dependent variable has increased up to 10.9 percent. The beta value also increased from 0.214 to 0.242 after moderating effect. In both situations the significance levels are less than 0.05 and it is assured the 95 percent confidence level. Therefore it is revealed that the impulsiveness trait is positively moderating the re- lationship between ethnocentrism and impulsive buying behaviour in the milk powder market.

\section{Conclusion and Recommen- dation}

The present study is focused on investigating the impact of the ethnocentrism trait of the dairy consumers on impulsive buying behaviour, when the relationship is moderated by the impulsiveness trait. According to the empirical evidences the three hypotheses of H1: Impulsiveness personality trait has a positive and medium effect on the relationship of the ethnocentrism and impulsive buying behavior, $\mathrm{H} 2$ : Sri Lanka milk powder customers have medium level of impulsiveness level, H3: Sri Lankan milk powder customers have medium involvement in ethnocentric appeal are accepted.

As per the empirical evidences, Sri Lankans are not very much ethnocentric when they decide on the purchasing the milk powder, they have a middle level of ethnocentric trait. But for certain extent Sri Lankans think that they should buy Sri Lankan products rather than foreign products. In Sri Lankan context impulsiveness is in the middle level. Sri Lankan milk powder product users are preplanning the purchasing decisions.

There is a positive relationship between Ethnocentrism and Impulsive Buying Behaviour in the milk powder market in Sri Lanka. Further when this relationship is moderated by the Impulsiveness trait of the consumer the relationship between the ethnocentrism and impulsive buying behaviour gets stronger. The consumers who have ethnocentric ideas have the impulsive ideas also. But when they do the purchasing sometimes goes with a preplanned purchasing decisions. Therefore all the local and multinational companies should get into activities that can stimulate and arouse the impulsiveness personality trait of the milk powder consumers. Then 
the consumers who have the ethnocentrism trait will stimulate to go for impulsive buying.

The multinational companies who lost their market share adversely are trying to come up with ethnocentric ideas with the promotional activities. But according to the study the customers are not very much concerned about the ethnocentrism when they get purchasing decisions in dairy market. The dairy product market is highly growing and competitive market.

The local and multinational companies should not only focus on Ethnocentrism angle to promote and develop the brand within the dairy users, but should focus on the arousal of the impulsiveness trait of the milk powder consumers.
For the newly coming researchers there are more researches to be done in the dairy market with the recent issues happened. Researchers can conduct research on what are the factors affecting to rebuild brand trust, what is the main criteria that customers concern when buying dairy products, what are the major factors that impact on impulsive buying in dairy market, how the marketers can arouse the impulsiveness trait of the milk powder consumers etc. From doing these research areas may help marketers and companies to get idea about what, how and where they should promote their brands in a successful way.

This study has certain limitations such as; survey was not conducted in whole country especially northern areas and the impact of ethnocentrism trait moderated by impulsiveness is tested, not the other factors in the market or consumer internal factors/stimuli are considered.

\section{Appendix A.}

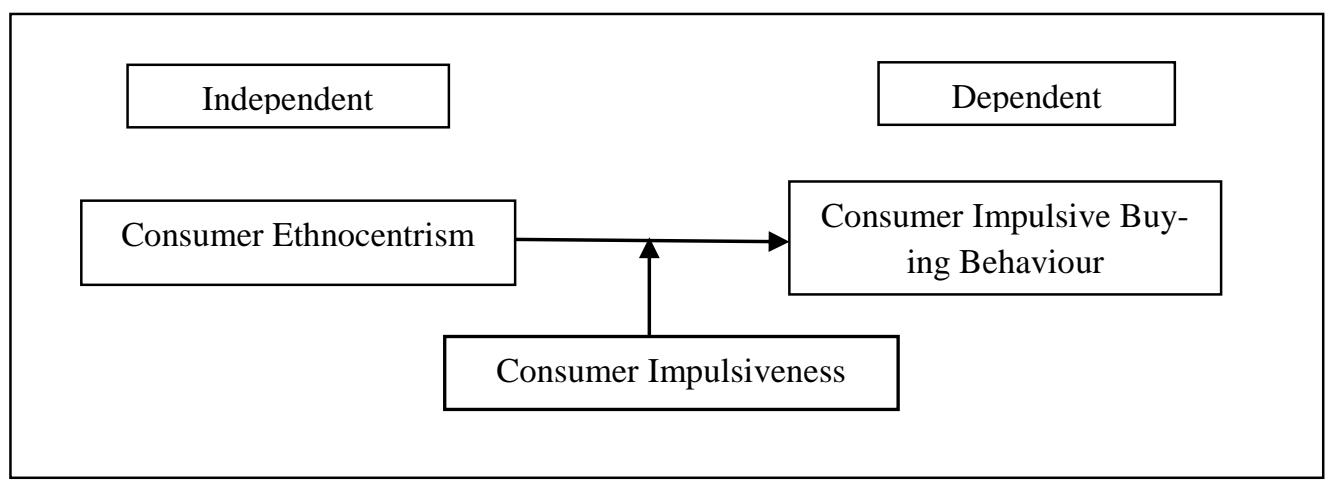

Figure 1. Conceptual framework

Source: Researchers developed

Table 1. Reliability Statistics

\begin{tabular}{|l|c|c|}
\hline \multicolumn{1}{|c|}{ Scale } & Cronbach's Alpha & No of Items \\
\hline Ethnocentrism (CETScale) & .910 & 17 \\
\hline Impulsiveness (BIScale) & .713 & 14 \\
\hline Impulsive Buying Behaviour & .811 & 6 \\
\hline
\end{tabular}

Source: Survey Data 
Table 2. Descriptive Statistics- Impulsiveness trait

\begin{tabular}{|l|c|c|c|}
\hline \multicolumn{1}{|c|}{ Item } & $\mathrm{N}$ & Mean & Std. Deviation \\
\hline I plan tasks carefully & 350 & 3.95 & .833 \\
\hline I do things without thinking & 350 & 2.50 & 1.000 \\
\hline I make up my mind quickly & 350 & 3.96 & .790 \\
\hline I do not pay attention & 350 & 2.15 & .903 \\
\hline I have racing thoughts & 350 & 4.09 & .653 \\
\hline I am self-controlled & 350 & 3.88 & .820 \\
\hline I concentrate easily & 350 & 4.08 & .677 \\
\hline I am a careful thinker & 350 & 3.86 & .711 \\
\hline I say things without thinking & 350 & 2.66 & .924 \\
\hline I act on impulse & 350 & 3.10 & 1.219 \\
\hline I act on the spur of the moment & 350 & 4.69 & .486 \\
\hline I am a steady thinker & 350 & 3.56 & .914 \\
\hline I buy things on impulse & 350 & 3.24 & 1.304 \\
\hline I spend or charge more than I earn & 350 & 2.39 & 1.091 \\
\hline Average & 350 & 3.43 & 0.41636 \\
\hline
\end{tabular}

Source: Survey Data

Table 3. Descriptive Statistics- Consumer Ethnocentrism

\begin{tabular}{|l|c|c|c|}
\hline \multicolumn{1}{|c|}{ Item } & $\mathrm{N}$ & Mean & $\begin{array}{c}\text { Std. Devia- } \\
\text { tion }\end{array}$ \\
\hline $\begin{array}{l}\text { Sri Lankan people should always buy Sri Lankan } \\
\text { made products instead of imports }\end{array}$ & 350 & 3.32 & 1.154 \\
\hline $\begin{array}{l}\text { Only those products that are unavailable in Sri } \\
\text { Lanka should be imported }\end{array}$ & 350 & 3.54 & 1.123 \\
\hline $\begin{array}{l}\text { Buy Sri Lankan made products. Keep Sri Lanka } \\
\text { working }\end{array}$ & 350 & 3.59 & 1.147 \\
\hline Sri Lankan products first, last and foremost & 350 & 3.48 & .948 \\
\hline Purchasing foreign made products is un Sri Lankan & 350 & 2.51 & 1.299 \\
\hline $\begin{array}{l}\text { It is not right to purchase foreign products, because } \\
\text { it puts Sri Lankans out of job }\end{array}$ & 350 & 2.63 & 1.261 \\
\hline $\begin{array}{l}\text { A real Sri Lankan should always buy Sri Lankan } \\
\text { made products }\end{array}$ & 350 & 2.99 & 1.243 \\
\hline $\begin{array}{l}\text { We should purchase products manufactured in Sri } \\
\text { Lanka instead of letting other countries get rich off } \\
\text { us }\end{array}$ & 350 & 3.72 & 1.102 \\
\hline \begin{tabular}{l} 
It is always better to purchase Sri Lankan products \\
\hline $\begin{array}{l}\text { There should be very little trading or purchasing of } \\
\text { goods from other countries unless out of necessity }\end{array}$
\end{tabular} & 350 & 3.62 & 1.042 \\
\hline
\end{tabular}




\begin{tabular}{|l|c|c|c|}
\hline $\begin{array}{l}\text { Sri Lankans should not buy foreign products, be- } \\
\text { cause this hits Sri Lankan business and causes un- } \\
\text { employment }\end{array}$ & 350 & 2.90 & 1.227 \\
\hline Curbs should be put on all imports & 350 & 3.73 & .962 \\
\hline $\begin{array}{l}\text { It may cost me in long run but I prefer to support } \\
\text { Sri Lankan products }\end{array}$ & 350 & 3.81 & 1.070 \\
\hline $\begin{array}{l}\text { Foreigners should not be allowed to put their prod- } \\
\text { ucts to our markets }\end{array}$ & 350 & 2.64 & 1.078 \\
\hline $\begin{array}{l}\text { Foreign products should be taxed heavily to reduce } \\
\text { their entry to Sri Lanka }\end{array}$ & 350 & 3.02 & 1.137 \\
\hline $\begin{array}{l}\text { We should buy from foreign countries only those } \\
\text { products we cannot obtain within our own country }\end{array}$ & 350 & 3.76 & .944 \\
\hline $\begin{array}{l}\text { Sri Lankan consumers who purchase products } \\
\text { made in other countries are responsible for putting } \\
\text { their fellow Sri Lankans out of work }\end{array}$ & 350 & 3.01 & 1.251 \\
\hline Average & 350 & 3.28 & .72154 \\
\hline
\end{tabular}

Source: Survey Data

Table 4. Descriptive Statistics - Impulsive Buying Behaviour

\begin{tabular}{|l|c|c|c|}
\hline \multicolumn{1}{|c|}{ Item } & $\mathrm{N}$ & Mean & $\begin{array}{c}\text { Std. Devia- } \\
\text { tion }\end{array}$ \\
\hline $\begin{array}{l}\text { Generally speaking, I would consider myself to be an } \\
\text { impulsive shopper }\end{array}$ & 350 & 2.78 & 1.055 \\
\hline I often buy things spontaneously & 350 & 3.46 & 0.945 \\
\hline $\begin{array}{l}\text { When I shop I tend to decide what I want to buy while I } \\
\text { am looking around in a store }\end{array}$ & 350 & 2.68 & 1.016 \\
\hline I carefully plan most of my purchases & 350 & 3.72 & 0.945 \\
\hline $\begin{array}{l}\text { When I go shopping, I buy things I had not intended to } \\
\text { purchase }\end{array}$ & 350 & 3.54 & 0.920 \\
\hline $\begin{array}{l}\text { Even when I see something I really like, I do not buy it } \\
\text { unless it is a planned purchase }\end{array}$ & 350 & 2.81 & 1.008 \\
\hline Average & 350 & 3.16 & .75839 \\
\hline
\end{tabular}

Source: Survey Data

Table 5. Correlation Summary

\begin{tabular}{|l|l|l|}
\hline \multicolumn{1}{|c|}{ Relationship } & \multicolumn{1}{c|}{ Value } & \multicolumn{1}{c|}{ Significance Level } \\
\hline Ethnocentrism with IBB & .214 & .000 \\
\hline Impulsiveness with IBB & .241 & .000 \\
\hline Ethnocentrism and Impulsiveness & -.103 & 0.052 \\
\hline
\end{tabular}

Source: Survey Data 
Table 6. Model Summary

\begin{tabular}{|l|l|l|}
\hline \multicolumn{1}{|c|}{ Item } & \multicolumn{1}{|c|}{$\begin{array}{c}\text { DV and IV relation- } \\
\text { ship }\end{array}$} & \multicolumn{1}{c|}{$\begin{array}{c}\text { DV and IV relationship moderated } \\
\text { by the MV }\end{array}$} \\
\hline Adjusted R square & 0.042 & 0.109 \\
\hline Beta & 0.214 & Ethnocentrism 0.242 \\
\cline { 2 - 3 } & & Impulsiveness MV 0.266 \\
\hline t value & 3.471 & Ethnocentrism 4.034 \\
\cline { 2 - 3 } & & Impulsiveness MV 4.436 \\
\hline Significance level & $.001 \quad$ Source: Survey Data & .000 \\
\hline
\end{tabular}

\section{References}

Ahmed , Z. U., Johnson, J. P., Yang, X., Fatt, C. F., \& Teng. (2004). Does country of origin matter for lowinvolment products? Intenational Marketing Review, 21(1), 102-120.

Arce, E., \& Santisteban, C. (2006). Impulsivity: a review. Psicothema, 18(2), 213-220.

Baumeister, R. F. (2002). Yielding to Temptation: Self-control failure, impulsive purchasing, and consumer.

Beatty, S., \& Ferrell, M. (1998). Impulse buying: modeling its precursors. Journal of Retailing, 74(2), 169-191.

Bogahawatte, C., \& Herath, J. (2006). Factors Affecting Import Shares of Powdered Milk and Other Milk Products and Their Implications in Sri Lanka. Sri Lankan Journal of Agricultural Economics, 8, 21-30. doi:10.4038/sjae.v8i0.1827

Chang, H. J., Eckman, M., \& Yan, R. N. (2011). Application of the StimulusOrganism-Response model to the retail environment: the role of hedonic motivation in impulse buying behavior. The International Review of Retail, Distribution and Consumer Research.

Dawson, S., \& Kim, M. (2009). External and internal trigger cues of impulse buying online: direct marketing . An International Journal, 3(1), 20-34.

Donovan, R., Rossiter, J., \& Marcoolyn, G. (1994). Store atmosphere and purchasing behavior. Journal of retailing, 70(3), 283-294.

Elliot, G., \& Cameron, R. (1994).

Consumer perception of product quality and the country of origin effect. Journal of International Marketing, 2(2), 49-62.

Engel, J., \& Blackwell, R. (1982).

Consumer Behavior. Chicago: Dryden Press.

Engel, J., \& Blackwell, R. (1982).

Consumer Behavior. Chicago: Chicago:

Dryden Press.

Evenden, J. L. (1999). Varieties of impulsivity . Psychopharmacology (Berl), 146, 348-361.

Gupta. (2009). Impact of Store Size on Impulse Purchase. The IUP Journal of Marketing Management, 8(1).

Gure, I. (2012). Understanding consumer's impulse buying behaviour. The Republic of Turkey: Graduate School of Social Sciences.

Han, Y., Morgan, G., Kotsiopulo, A., \& Kang -Park, J. (1991). Impulse buying behavior of apparel purchasers. Clothing and Textiles Research Journal, 9(3), 1521. 
Herche , J. (1992). A note on the predictive validity of the CETSCALE . Journal of the Academy of Marketing Science, 20(3), 261-264.

Hulten, P., \& Vanyushyn, V. (2011). Impulse purchases of groceries in France and Sweden . Journal of Consumer Marketing, 25, 376-384.

John, Scott, A. C., Deborah , R., \& James , R. (1986). Sampling Data for Covariation Assessment: The Effect of Prior Beliefs on Search Pattems . Journal of Consumer Research, 13, 38-47.

Kaynak, E., \& Kara, A. (2002). Consumer perceptions of foreign products . European Journal of Marketing, 36(7/8), 928-949. Retrieved from http://dx.doi.org/10.1108/026513308108 87477

Klein , J. D., Brown, J. D., Childers, K. W., Oliveri, J., Porter, C., \& Dykers, C. (1993). Adolescents' risky behaviour and mass media use. Pediatrics, 92, 24-31.

Mangaleswaran, T., Morais, N., \& Jeyaseelan, G. (2010). Dairy market trends in Vavuniya: identifying potentials and challenges in a post-conflict setting. International Conference on Business \& Information 2010. University of Kelaniya.

Mangaleswaran., T., Morais, N., \& Jeyaseelan, G. (2010). Dairy Market Trends in Vavuniya: Identifying Potentials and Challenges in a Postconflict setting. International Conference on Business \& Information 2010, University of Kelaniya.

Mattila, A., \& Enz, C. (2002). The role of emotions in service encounters .

Journal Of Service Research, 4(4), 268277.

Mattila, A., \& Wirtz, J. (2008). The role of store environmental stimulation and social factors on impulse purchasing.
Journal of Services Marketing, 22(7), 562-567.

Monterosso, J., \& Ainslie, G. (1999). Beyond discounting: possible experimental models of impulse control. Psychopharmacology (Berl), 146, 339347.

Muruganantham, G., \& Kaliyamoorthy, S. (2005, June). Retail Revolution, Marketing Mastermind. 15-21.

Nisbett, Richard , \& Ross, L. (1980). Human inference strategies and shortcomings of social judgment. Englewood cliffs, NJ: Prentice-Hall, Inc.

O'Guinn, T. C., \& Faber, R. J. (1989). Compulsive buying: a phenomenological exploration. The Journal of Consumer Research, 16(2), 147-157.

Ramaswamy , \& Namakumar. (2009). Marketing Management (Vol. 4th edition). New Delhi: McMillan Publishing.

Ranaweera, N. C. (2010). Smallholder diary development- lessons learned in Asia.

Reardon, J., Miller, C., Vida , I., \& Kim , I. (2005). The effects of ethnocentrism and economic development on the formation of brand and ad attitudes in transitional economies. European Journal of Marketing, 39, 737-754.

Renko, N., Karanovic, B. C., \& Matic, M. (2012). Influence of consumer ethnocentrism on purchasing intentions: case of Croatia . Ekon Misao Praksa Dbk, 529-544.

Rook, D. W. (1993). 'In the mood: impulse buying's affective antecedents. Research in consumer behavior, vol. 6, no.7, pp.1-28.

Rook, D. W., \& Gardner, M. P. (1993). In the mood: impulse buying's affective 
antecedents. Research in consumer behavior, 6(7), 1-28.

Rook, D., \& Hoch, S. (1985). Consuming impulses . Advances in Consumer Research, 7(1), 23-27.

Shimp , T., \& Sharma, S. (1987). Consumer ethnocentrism: construction and validation of the CETScale. Journal of Marketing Research, xxiv, 280-289.

Shoham, A., \& Brencic, M. (2003). Consumer ethnocentrism, attitudes and purchase behaviour: a Israeli study. Journal of International Consumer Marketing, 15(4), 67-86.

Stern, H. (1962, April). The significance of impulse buying today. Journal of Marketing, 59-62.

Supphellen, M., \& Grønhaug, K. (2003). Builiging foreign brand personalities in Russia: the moderating effect of consumer ethnocentrism. International Journal of Advertising, 203-226.

Wanninayake, W., \& Chovancova, M. (2012). Exploring the impact of consumer ethnocentrism on impulsive buying decisions: with evidence from Sri Lanka. Advances in Economics, Risk
Management, Political and Law Science, 247-251.

Weinberg, P., \& Gottwald, W. (1982).

Impulsive consumer buying as a result of emotions. Journal of Business research, 10(1), 43-57.

Youn, S., \& Faber, R. (2000). Impulse buying: its relation to personality traits and cues. Advances on Consumer Research, 27, 179-185.

Yu, C., \& Bastin, M. (2010). Hedonic shopping value and impulse buying behavior in transitional economies: Asymbiosis in the Mainland China marketplace. Journal of Brand Management, 18(2), 105-114.

Zhou, L., \& Wong, A. (2004). Consumer impulse buying and in-store stimuli in Chinese supermarkets. Journal of International Consumer Marketing, 16(2), 37-53. 